\title{
Audiometria de reforço visual com diferentes estímulos sonoros em crianças***
}

\author{
Visual reinforcement audiometry with different sound stimuli in \\ children
}

\author{
Eliara Pinto Vieira* \\ Marisa Frasson de Azevedo**
}

\begin{abstract}
* Fonoaudióloga. Mestre em Distúrbios da Comunicação Humana pela Universidade Federal de São Paulo - Escola Paulista de Medicina. Colaboradora do Núcleo Integrado de Atendimento, Pesquisa e Ensino em Audição (NIAPEA) do Departamento de Fonoaudiologia da Universidade Federal de São Paulo. Endereço para correspondência: Rua Borges Lagoa, 512/92B - São Paulo - SP - CEP 04038-001 (eliarapv@yahoo.com.br).
\end{abstract}

**Fonoaudióloga. Doutora em Distúrbios da Comunicação Humana pela Universidade Federal de São Paulo. Professora Adjunto IV do Departamento de Fonoaudiologia da Universidade Federal de São Paulo.

***Trabalho Realizado no Núcleo Integrado de Atendimento, Pesquisa e Ensino em Audição (NIAPEA) do Departamento de Fonoaudiologia da Universidade Federal de São Paulo Escola Paulista de Medicina, para a Obtenção do Título de Mestre em Distúrbios da Comunicação Humana, com Apoio Financeiro do Conselho Nacional de Desenvolvimento Científico e Tecnológico (CNPq).

Artigo de Pesquisa

Artigo Submetido a Avaliação por Pares

Conflito de Interesse: não

Recebido em: 27.12.2005.

Revisado em: 06.04.2006; 06.09.2006; 14.09.2006; 27.11.2006.

Aceito para Publicação em 25.04.2007.

\begin{abstract}
Background: hearing evaluation in children. Aim: to verify the Minimum Response Levels (MRL) through the use of Visual Reinforcement Audiometry (VRA) in the sound field, in 50 normal hearing children and in 25 children with hearing loss, taking into account the following variables: side of sound presentation, gender, age and type of stimulus. Method: VRA was performed using pure tone frequency modulation (warble) and the Sonar System. The modulated tones were produced by the Pediatric Audiometer, in the frequencies of $500,1000,2000$ and $4000 \mathrm{~Hz}$ and at the intensities of $80,60,40$ and 20dBNA. The modulated tones were presented in a decreasing sequence of intensity and by using the stimulus-reply-visual reinforcement conditioning. The assessment procedure and analysis of response were the same when using the stimuli of the Sonar System. However, on this occasion, a sound amplification box was used. Each loudspeaker with the visual reinforcement was positioned approximately at $90^{\circ}$ azimuth to the right and the left of the child, and at a distance of approximately $50 \mathrm{~cm}$. Visual reinforcement was an illuminated clown. Results: no statistically significant difference was found between the MNL and the side of sound presentation. The MRL at $500 \mathrm{~Hz}$ and $2000 \mathrm{~Hz}$, when using the Sonar System, were lower for normal hearing males. In this group, there was a decrease in the MRL with the increase in age for both stimuli. When comparing the MRL with two stimuli, there was a statistically significant difference in favor of the Sonar System, but only for the group of normal hearing children below two years of age. Conclusion: the MRL decrease with age independently of the stimulus and are lower when using the Sonar System. For the group of children with hearing loss no significant difference was found for any of the studied variables.
\end{abstract}

Key Words: Hearing; Children; Hearing Tests.

\section{Resumo}

Tema: avaliação auditiva infantil. Objetivo: verificar os Níveis Mínimos de Resposta (NMR) por meio de Audiometria de Reforço Visual (ARV) em campo livre, em 50 crianças ouvintes e 25 deficientes auditivas, considerando as variáveis: lado de apresentação sonora, sexo, idade e tipo de estímulo. Método: realizou-se ARV com tons puros modulados em freqüência (warble) e com estímulos do Sistema Sonar nas crianças selecionadas. Os tons modulados foram produzidos pelo Audiômetro Pediátrico, nas frequiências de 500, 1000, 2000 e 4000Hz e nas intensidades de 80, 60, 40 e 20dBNA. Sendo estes apresentados em ordem decrescente de intensidade e utilizando o condicionamento estímulo-resposta-reforço visual. Utilizando os estímulos Sistema Sonar, o procedimento de avaliação e a apreciação das respostas foram os mesmos, porém para a apresentação destes foi utilizada uma caixa de amplificação sonora. Cada alto-falante com o reforço visual foi posicionado a aproximadamente a 90 azimute à direita e à esquerda da criança, em uma distância de aproximadamente $50 \mathrm{~cm}$. O reforço visual usado foi um palhaço iluminado. Resultados: não houve diferença estatisticamente significante entre MNR em relação ao lado de apresentação. Os NMRs em 500 e $2000 \mathrm{~Hz}$ do Sistema Sonar, foram menores no sexo masculino nos ouvintes. Neste grupo houve diminuição dos NMR com aumento da idade, para ambos estímulos. Ao comparar NMRs com dois estímulos houve diferença estatisticamente significante a favor do Sistema Sonar apenas para ouvintes com menos de dois anos. Conclusão: em ouvintes os NMRs reduzem com avanço da idade independente do estímulo e são inferiores com o Sistema Sonar. Nas deficientes auditivas não houve diferença significativa em relação a nenhuma variável estudada.

Palavras-Chave: Audição; Criança; Testes Auditivos. 


\section{Introduction}

There is a direct relation between hearing and language acquisition, that is, the integrity of auditory pathways is a pre-requisite for the speech and language development (Northern \& Downs, 1991).

Therefore, the early detection of hearing disorders is of great importance in order to prevent the developmental disorders that occur in children who do not receive proper sound stimulation in their first years of life (Lichtig et al., 2001; Aita et al., 2002 \& Oliveira et al., 2002).

Nowadays there are several procedures for children's hearing evaluation, from behavioral to physiological and/or electrophysiological methodologies, such as the otoacoustic emissions and the auditory brainstem evoked potentials (Jacobson \& Jacobson, 2004).

One of the main behavioral techniques to evaluate the hearing sensitivity of small children is the Visual Reinforcement Audiometry (VRA), proposed by Lindén and Kankkunen (1969). This procedure aims at conditioning the child with a sound stimulus associated with a light; when the child looks for the sound source, the examiner offers a visual stimulus as a reinforcement (Sirimanna, 2001 and Widen \& O'Grady, 2002).

The stimuli may be presented in a free field, through loud speakers, supra-auricular earphones, insertion phones or even through bone vibrators (Day et al., 2000; Widen et al., 2001; Sirimanna, 2001; Sininger, 2003 and Delaroche et al., 2004).

Many studies about the types of reinforcements used in the Visual Reinforcement Audiometry are published, but, in general, the authors suggest the use of animated lighted toys (Jayarajan et al., 2005) and child movies presented from DVDs (Schmida et al., 2003).

Concerning the stimuli used in the child's hearing evaluation, the most commonly used one is the frequency modulated pure tone (warble), which according to Oda et al. (2003) facilitates the sound stimulus perception for the determination of the hearing threshold. Nevertheless, Poblano et al. (2000) believe that non calibrated sound stimuli produced by sound instruments or toys have greater meaning and are more stimulating for small children. However, it is not possible to maintain the same intensity of the instrumental stimuli in different presentations. Furthermore, several instruments present similar spectra which makes the use of many of them unnecessary (Poblano et al., 2000 and Chirelli et al., 2002). In order to minimize this procedure's limitations, Lima et al. (2001) created the Sonar System, that proposes the use of percussion instruments sounds filtered and normalized in amplitude and duration, presented from CDs, and guarantying the amplitude, time and frequency reproducibility.

The Sonar System is composed by three CDs with filtered instruments signals and frequency modulated ones, lasting two, 10 and 20 seconds, limited in octave, half-octave and third-octave band, centered in the frequencies commonly used in an audiological assessment. Initially, several instruments sounds, used in an instrumental evaluation, were recorded. All of them were filtered, the complex sounds characteristics were preserved, even the percussion rhythm was maintained. The signals were recorded digitally, in a recording environment with noise level below 35dBA. Next, the filtered sound was normalized in amplitude. From the instruments initially recorded, eight were selected, one for each centered frequency in such a way that the recording rhythm variations would postpone the habituation. The filtered signals present effective energy only in specific frequency bands, with identical rhythm to the original signal (Lima et al., 2001).

Since there is an increasing number of researches in the area of children's hearing evaluation, and since the Sonar System is an innovator procedure once it offers instrumental stimuli that are familiar to children, with intensity and frequency determined by the examiner, this study aims at:

Verifying the minimum response levels (MRL) in normal hearing children and in children with bilateral sensorineural hearing loss throughout Visual Reinforcement Audiometry (VRA) in free field, considering the variables sound presentation side, sex, age and type of stimulus.

\section{Method}

This research was developed in the 
Integrated Assistance, Research and Teaching Nucleus on Hearing - NIAPEA, of the Federal University of São Paulo, with the approval of the Institution's Research Ethics Committee (CEP 0731/04).

Parents and/or caretakers who agreed with their children's participation in the research signed the Informed Consent Term.

The sample was composed by 75 children, male and female, ranging in age from 6 to 34 months, distributed in two groups according to their hearing condition: Group I: 50 children with normal hearing; Group II: 25 children with bilateral sensorineural hearing loss.

These two groups were subdivided according to the child's age at the moment of the evaluation: 6-12 months; 13-24 months; and over 24 months (Table 1).

The inclusion criteria for each one of the groups were as follows: Group I: (1) absence of risk indicators for hearing loss, (2) presence of bilateral otoacoustic emissions evoked by transient stimulus and (3) type A tympanometric curve in the moment of the evaluation. Group II: (1) absence of otoacoustic emissions evoked by transient stimulus and (2) auditory brainstem evoked potentials indicating hearing loss.

The Minimum Response Level (MRL) with two different sound stimuli was investigated in the selected children.

MRL with frequency modulated pure tones (warble)

These stimuli were produced by the Interacoustics Pediatric Audiometer PA2, at $500,1000,2000$ and $4000 \mathrm{~Hz}$ and at 80, 60, 40 and $20 \mathrm{dBNA}$. The stimuli were presented in decreasing intensities using the conditioning stimulus-response-visual reinforcement. The child was positioned on the caretaker's lap facing a test assistant. The examiner presented the sound stimulus out of the child's visual field on the right and then on the left side, at approximately $20 \mathrm{~cm}$ from the auricular pavilion.

The evaluation took place in a sound proof cabin. The expected response was that the child looked to the side where the sound stimulus was coming from. Soon after the correct localization of the sound source, the examiner presented the visual stimulus of the pediatric audiometer (three red lights). The weakest intensity in which there was a sound localization was considered the MRL.

MRL with instrumental sounds filtered and normalized in amplitude and duration (Sonar System)

This procedure was performed in the same condition as the previous one, however for the presentation of the Sonar System stimuli an amplifier, normally used in free field audiological evaluations was used. Each loudspeaker with the visual reinforcement was positioned at approximately 90 azimuth on the right and on the left of the child, with a distance of approximately $50 \mathrm{~cm}$. The visual reinforcement used was a lighted clown.

The Madsen Electronics NOAH software "aurical" was used coupled to a Panasonic digital compact disc player. Before data collecting, the equipments were calibrated according to the test's signal characteristics and to the acoustic conditions of the setting. The sound pressure levels of the stimuli were checked in the location of the test. These measures were obtained with a Radio Shack digital Sound Level Meter. The sound level meter was positioned towards the loudspeaker at the same distance used previously for the sample evaluation. The A scale was used once it is recommended for the measurement of intermittent noises.

The stimuli used were the ones recommended for children over three months of age since they present greater frequency specificity - third-octave band, and lesser presentation duration - two seconds (CD number 1). These stimuli represented the frequencies of: $500 \mathrm{~Hz}$, track number 35 of the first CD (drum); $1000 \mathrm{~Hz}$, track number 39 (afochê); $2000 \mathrm{~Hz}$, track number 43 (castanet) and $4000 \mathrm{~Hz}$, track number 47 (reco-reco).

The evaluation procedure and the responses appreciation were the same as the frequency modulated pure tones, the maximum intensity of the sound stimulus was $80 \mathrm{~dB}$, but it was possible to decrease it from 10 to $10 \mathrm{~dB}$, and the minimum intensity of presentation was $10 \mathrm{~dB}$.

Children were evaluated in the presence of the parents and/or caretakers and the evaluation was performed by an examiner and an assistant in order to check the responses and help to condition them. 
The statistical model adopted in this study involved Anova tests, Survival Analysis and Equality of Two Proportions Analysis, and for complementing the descriptive analysis the Confidence Interval technique was used.

The significance level adopted in this study was $0,05(5 \%)$ and all confidence intervals were built with $95 \%$ of statistical confidence.

\section{Results}

All children from the sample were evaluated in only one session, and all of them completed the evaluation allowing the investigation of the minimum response level (MRL) at the four evaluated frequencies (500, 1000,2000 and $4000 \mathrm{~Hz}$ ) with the two selected stimuli for this research. The average time of evaluation was 15 minutes; the maximum time was 25 minutes and the minimum, 12 minutes.

The MRLs obtained with the presentation of the sound stimuli on the right were similar to the ones obtained on the left, without statistical differences between the presentation sides for either group I or group II, independently of the type of stimulus used. Thus, the sample could be grouped disregarding the variable presentation side.

Concerning the variable sex, there was no significant statistical difference in the MRL according to the sex in normal hearing children when the frequency modulated pure tone was used in the VRA. Nevertheless, when the Sonar System stimuli were used, there was a difference between the sexes that can be seen in Table 2. The statistical analysis results are described in the bottom of the table.

In group II composed by children with symmetrical bilateral sensorineural hearing loss, no significant statistical difference was found between the sexes when the MRL was investigated with both types of stimuli.

The MRL results for frequency modulated pure tones according to the variable age in the normal hearing children are described in Table 3.

It can be concluded that at all frequencies there is an average difference statistically significant between the three age groups simultaneously. It was necessary, then, to compare all tracks two by two in order to find out in which one of them the difference is occurring (Tukey Multiple Comparison) in Table 4.

The MRL results for the Sonar System instrumental sounds according to the variable age group in children with normal hearing are described in Table 5.

With the Sonar System instrumental sounds it was also found significant statistical difference between the age groups. Table 6 shows the p-values of the comparison twoby-two between the groups in all frequencies.

There was no significant statistical difference in group II between the average MRL obtained with frequency modulated pure tones and with the Sonar System stimuli in all age groups.

It was also analyzed whether the average MRL differed regarding the different types of stimuli. The data presented in Table 7, 8, 9 and 10 show the MRL analysis with the two sound stimuli at the different frequencies for normal hearing children distributed in the evaluated age groups.

It was observed in children with hearing loss a significant statistical difference favoring the Sonar System instrumental sounds in the age group of 13 to 24 only at the frequency of $1000 \mathrm{~Hz}$ (Table 11).

TABLE 1. Sample characterization:

\begin{tabular}{lccc}
\hline & male & female & \\
\hline & $\mathrm{n}(\%)$ & $\mathrm{n}(\%)$ & 50 \\
\hline Group I & $25(50 \%)$ & $25(50 \%)$ & 25 \\
\hline Group II & $11(44 \%)$ & $14(56 \%)$ & 75 \\
\hline Total & $36(48 \%)$ & $39(52 \%)$ & \\
\hline
\end{tabular}


TABLE 2. MRL for instrumental sounds filtered and normalized in amplitude and duration, in normal hearing children according to the sex

\begin{tabular}{|c|c|c|c|c|c|c|c|c|}
\hline \multirow{2}{*}{ Sonar System Group I } & \multicolumn{2}{|c|}{$500 \mathrm{~Hz}$} & \multicolumn{2}{|c|}{$1 \mathrm{kHz}$} & \multicolumn{2}{|c|}{$2 \mathrm{kHz}$} & \multicolumn{2}{|c|}{$4 \mathrm{kHz}$} \\
\hline & Fem. & Male. & Fem. & Male. & Fem. & Male. & Fem. & Male. \\
\hline Average & 32,00 & 27,60 & 26,60 & 23,20 & 26,20 & 22,40 & 26,80 & 23,20 \\
\hline Standard deviation & 9,26 & 9,38 & 8,72 & 8,68 & 9,23 & 9,16 & 9,78 & 9,13 \\
\hline Minimum & 20 & 10 & 10 & 10 & 10 & 10 & 10 & 10 \\
\hline Size & 25 & 25 & 25 & 25 & 25 & 25 & 25 & 25 \\
\hline Inferior limit & 29,43 & 25,00 & 24,18 & 20,80 & 23,64 & 19,86 & 24,09 & 20,67 \\
\hline Superior limit & 34,57 & 30,20 & 29,02 & 25,60 & 28,76 & 24,94 & 29,51 & 25,73 \\
\hline p-value & \multicolumn{2}{|c|}{$\mathbf{0 , 0 2 0 *}$} & \multicolumn{2}{|c|}{$0,053 \#$} & \multicolumn{2}{|c|}{$0,041 *$} & \multicolumn{2}{|c|}{$0,060 \#$} \\
\hline
\end{tabular}

Fem $=$ Female

TABLE 3. MRL for frequency modulated pure tone in normal hearing children according to the age

\begin{tabular}{|c|c|c|c|c|c|c|c|c|c|c|}
\hline \multicolumn{2}{|c|}{$\begin{array}{l}\text { Modulated pure tone } \\
\text { Group I }\end{array}$} & Average & Median & $\begin{array}{l}\text { Standard } \\
\text { deviation }\end{array}$ & Minimum & Maximum & Size & $\begin{array}{c}\text { Inferior } \\
\text { limit }\end{array}$ & $\begin{array}{l}\text { Superior } \\
\text { limit }\end{array}$ & p-value \\
\hline \multirow{3}{*}{$500 \mathrm{~Hz}$} & 6 to $12 \mathrm{~m}$ & 40,00 & 40 & 9,18 & 20 & 60 & 29 & 37,64 & 42,36 & \multirow{3}{*}{$<0,001 *$} \\
\hline & 13 to $24 \mathrm{~m}$ & 32,86 & 40 & 9,76 & 20 & 40 & 14 & 29,24 & 36,47 & \\
\hline & $>24 \mathrm{~m}$ & 28,57 & 20 & 10,27 & 20 & 40 & 07 & 23,19 & 33,95 & \\
\hline \multirow{3}{*}{$1 \mathrm{kHz}$} & 6 to $12 \mathrm{~m}$ & 32,76 & 40 & 9,70 & 20 & 40 & 29 & 30,26 & 35,25 & \multirow{3}{*}{ 0,001* } \\
\hline & 3 to $24 \mathrm{~m}$ & 27,14 & 20 & 9,76 & 20 & 40 & 14 & 23,53 & 30,76 & \\
\hline & $>24 \mathrm{~m}$ & 22,86 & 20 & 7,26 & 20 & 40 & 07 & 19,05 & 26,66 & \\
\hline \multirow{3}{*}{$2 \mathrm{kHz}$} & 6 to $12 \mathrm{~m}$ & 31,72 & 40 & 9,94 & 20 & 40 & 29 & 29,17 & 34,28 & \multirow{3}{*}{$<0,001 *$} \\
\hline & 13 to $24 \mathrm{~m}$ & 27,14 & 20 & 9,76 & 20 & 40 & 14 & 23,53 & 30,76 & \\
\hline & $>24 \mathrm{~m}$ & 20,00 & 20 & - & 20 & 20 & 07 & - & - & \\
\hline \multirow{3}{*}{$4 \mathrm{kHz}$} & 6 to $12 \mathrm{~m}$ & 33,10 & 40 & 10,96 & 20 & 60 & 29 & 30,28 & 35,92 & \multirow{3}{*}{ 0,001* } \\
\hline & 13 to $24 \mathrm{~m}$ & 30,00 & 30 & 10,18 & 20 & 40 & 14 & 26,23 & 33,77 & \\
\hline & $>24 \mathrm{~m}$ & 21,43 & 20 & 5,35 & 20 & 40 & 07 & 18,63 & 24,23 & \\
\hline
\end{tabular}

TABLE 4. "p-values" for the different evaluated frequencies with frequency modulated pure tone according to the age groups in normal hearing children.

\begin{tabular}{llll}
\hline & AP - Group 1 & 6 to $12 \mathrm{~m}$ & 13 to $24 \mathrm{~m}$ \\
\hline \multirow{2}{*}{$500 \mathrm{~Hz}$} & 13 to $24 \mathrm{~m}$ & $\mathbf{0 , 0 0 4} *$ & \\
\cline { 2 - 4 } & $>24 \mathrm{~m}$ & $<\mathbf{0 , 0 0 1 *}$ & 0,356 \\
\hline \multirow{2}{*}{$1 \mathrm{kHz}$} & 13 to $24 \mathrm{~m}$ & $\mathbf{0 , 0 3 0 *}$ & 0,350 \\
\cline { 2 - 4 } & $>24 \mathrm{~m}$ & $\mathbf{0 , 0 0 2} *$ & \\
\hline \multirow{2}{*}{$2 \mathrm{kHz}$} & 13 to $24 \mathrm{~m}$ & $0,082 \#$ & $0,051 \#$ \\
\cline { 2 - 4 } & $>24 \mathrm{~m}$ & $<\mathbf{0 , 0 0 1 *}$ & \\
\hline \multirow{2}{*}{$4 \mathrm{kHz}$} & 13 to $24 \mathrm{~m}$ & 0,384 & $\mathbf{0 , 0 3 1 *}$ \\
\cline { 2 - 4 } & $>24 \mathrm{~m}$ & $\mathbf{0 , 0 0 1 *}$ & \\
\hline
\end{tabular}


TABLE 5. MRL for instrumental sounds in normal hearing children according to the age groups.

\begin{tabular}{|c|c|c|c|c|c|c|c|c|c|c|}
\hline \multicolumn{2}{|c|}{$\begin{array}{l}\text { Sonar System } \\
\text { Group I }\end{array}$} & \multirow{2}{*}{$\begin{array}{c}\text { Average } \\
32,24\end{array}$} & \multirow{2}{*}{$\begin{array}{c}\text { Median } \\
30\end{array}$} & \multirow{2}{*}{$\begin{array}{c}\begin{array}{c}\text { Standard } \\
\text { deviation }\end{array} \\
10,27\end{array}$} & \multirow{2}{*}{$\begin{array}{c}\text { Minimum } \\
10\end{array}$} & \multirow{2}{*}{$\begin{array}{c}\text { Maximum } \\
50\end{array}$} & \multirow{2}{*}{$\begin{array}{c}\text { Size } \\
29\end{array}$} & \multirow{2}{*}{$\begin{array}{c}\text { Inferior limit } \\
29,60\end{array}$} & \multirow{2}{*}{$\begin{array}{c}\text { Superior } \\
\text { limit }\end{array}$} & \multirow{3}{*}{$\begin{array}{c}\text { p-value } \\
\mathbf{0 , 0 0 5 *}\end{array}$} \\
\hline & 6 to $12 \mathrm{~m}$ & & & & & & & & & \\
\hline \multirow[t]{3}{*}{$500 \mathrm{~Hz}$} & 13 to $24 \mathrm{~m}$ & 27,50 & 30 & 7,01 & 20 & 40 & 14 & 24,91 & 30,09 & \\
\hline & $>24 \mathrm{~m}$ & 24,29 & 20 & 7,56 & 20 & 40 & 07 & 20,33 & 28,25 & \\
\hline & 6 to $12 \mathrm{~m}$ & 27,07 & 30 & 9,55 & 10 & 40 & 29 & 24,61 & 29,53 & \\
\hline \multirow[t]{3}{*}{$1 \mathrm{kHz}$} & 13 to $24 \mathrm{~m}$ & 22,14 & 20 & 7,87 & 10 & 40 & 14 & 19,23 & 25,06 & $0,013 *$ \\
\hline & $>24 \mathrm{~m}$ & 21,43 & 20 & 3,63 & 20 & 30 & 07 & 19,53 & 23,33 & \\
\hline & 6 to $12 \mathrm{~m}$ & 26,72 & 30 & 9,80 & 10 & 40 & 29 & 24,20 & 29,25 & \\
\hline \multirow[t]{3}{*}{$2 \mathrm{kHz}$} & 13 to $24 \mathrm{~m}$ & 20,71 & 20 & 9,00 & 10 & 40 & 14 & 17,38 & 24,05 & 0,008* \\
\hline & $>24 \mathrm{~m}$ & 21,43 & 20 & 3,63 & 20 & 30 & 07 & 19,53 & 23,33 & \\
\hline & 6 to $12 \mathrm{~m}$ & 27,41 & 30 & 10,18 & 10 & 40 & 29 & 24,79 & 30,03 & \\
\hline \multirow[t]{2}{*}{$4 \mathrm{kHz}$} & 13 to $24 \mathrm{~m}$ & 21,79 & 20 & 9,05 & 10 & 40 & 14 & 18,43 & 25,14 & 0,011* \\
\hline & $>24 \mathrm{~m}$ & 21,43 & 20 & 3,63 & 20 & 30 & 07 & 19,53 & 23,33 & \\
\hline
\end{tabular}

TABLE 6. p-values for the different frequencies with instrumental sounds in normal hearing children evaluated according to the age groups

\begin{tabular}{llll}
\hline \multicolumn{2}{c}{ Sonar System - Group I } & 6 to $12 \mathrm{~m}$ & 13 to $24 \mathrm{~m}$ \\
\hline \multirow{2}{*}{$500 \mathrm{~Hz}$} & 13 to $24 \mathrm{~m}$ & $0,067 \#$ & \\
\cline { 2 - 4 } & $>24 \mathrm{~m}$ & $\mathbf{0 , 0 1 2 *}$ & 0,531 \\
\hline \multirow{2}{*}{$1 \mathrm{kHz}$} & 13 to $24 \mathrm{~m}$ & $\mathbf{0 , 0 3 6 ^ { * }}$ & 0,965 \\
\cline { 2 - 4 } & $>24 \mathrm{~m}$ & $0,072 \#$ & \\
\hline \multirow{2}{*}{$2 \mathrm{kHz}$} & 13 to $24 \mathrm{~m}$ & $\mathbf{0 , 0 1 3} *$ & 0,968 \\
\cline { 2 - 4 } & $>24 \mathrm{~m}$ & 0,123 & 0,992 \\
\hline \multirow{2}{*}{$4 \mathrm{kHz}$} & 13 to $24 \mathrm{~m}$ & $\mathbf{0 , 0 2 6 *}$ & $0,081 \#$ \\
\cline { 2 - 4 } & $>24 \mathrm{~m}$ & & \\
\hline
\end{tabular}

TABLE 7. Comparison between the MRL for frequency modulated pure tone versus instrumental sounds filtered and normalized in amplitude and duration in normal hearing children at $500 \mathrm{~Hz}$

\begin{tabular}{|c|c|c|c|c|c|c|}
\hline \multirow{2}{*}{$\begin{array}{l}500 \mathrm{~Hz} \\
\text { Group I }\end{array}$} & \multicolumn{2}{|c|}{6 to $12 \mathrm{~m}$} & \multicolumn{2}{|c|}{13 to $24 \mathrm{~m}$} & \multicolumn{2}{|c|}{ over $24 \mathrm{~m}$} \\
\hline & PA & Sonar & PA & Sonar & PA & Sonar \\
\hline Average & 40,00 & 32,24 & 32,86 & 27,50 & 28,57 & 24,29 \\
\hline Median & 40 & 30 & 40 & 30 & 20 & 20 \\
\hline Standard deviation & 9,18 & 10,27 & 9,76 & 7,01 & 10,27 & 7,56 \\
\hline Minimum & 20 & 10 & 20 & 20 & 20 & 20 \\
\hline Maximum & 60 & 50 & 40 & 40 & 40 & 40 \\
\hline Size & 58 & 58 & 28 & 28 & 14 & 14 \\
\hline Inferior limit & 37,64 & 29,60 & 29,24 & 24,91 & 23,19 & 20,33 \\
\hline Superior limit & 42,36 & 34,88 & 36,47 & 30,09 & 33,95 & 28,25 \\
\hline p-value & \multicolumn{2}{|c|}{$<0,001 *$} & \multicolumn{2}{|c|}{$0,022 *$} & \multicolumn{2}{|c|}{0,220} \\
\hline
\end{tabular}


TABLE 8. Comparison between the MRL for frequency modulated pure tone versus instrumental sounds filtered and normalized in amplitude and duration in normal hearing children at $1000 \mathrm{~Hz}$

\begin{tabular}{ccccccc}
\hline \multirow{2}{*}{\begin{tabular}{c} 
Group I \\
\cline { 2 - 7 }
\end{tabular}} & PA & Sonar & PA & Sonar & PA & over 24m \\
\hline Average & 32,76 & 27,07 & 27,14 & 22,14 & 22,86 & 21,43 \\
\hline Median & 40 & 30 & 20 & 20 & 20 & 20 \\
\hline $\begin{array}{c}\text { Standard } \\
\text { deviation }\end{array}$ & 9,70 & 9,55 & 9,76 & 7,87 & 7,26 & 3,63 \\
\hline Minimum & 20 & 10 & 20 & 10 & 20 & 20 \\
\hline Maximum & 40 & 40 & 40 & 40 & 40 & 30 \\
\hline Size & 58 & 58 & 28 & 28 & 14 & 14 \\
\hline Inferior limit & 30,26 & 24,61 & 23,53 & 19,23 & 19,05 & 19,53 \\
\hline Superior limit & 35,25 & 29,53 & 30,76 & 25,06 & 26,66 & 23,33 \\
\hline p-value & & $\mathbf{0 , 0 0 2} *$ & $\mathbf{0 , 0 3 9 *}$ & 0,516 \\
\hline
\end{tabular}

TABLE 9. Comparison between the MRL for frequency modulated pure tone versus instrumental sounds filtered and normalized in amplitude and duration in normal hearing children at $2000 \mathrm{~Hz}$

\begin{tabular}{|c|c|c|c|c|c|c|}
\hline \multirow{2}{*}{$\begin{array}{c}2000 \mathrm{~Hz} \\
\text { Group I }\end{array}$} & \multicolumn{2}{|c|}{6 to $12 \mathrm{~m}$} & \multicolumn{2}{|c|}{13 to $24 \mathrm{~m}$} & \multicolumn{2}{|c|}{ over $24 \mathrm{~m}$} \\
\hline & PA & Sonar & PA & Sonar & $\mathrm{PA}$ & Sonar \\
\hline Average & 31,72 & 26,72 & 27,14 & 20,71 & 20,00 & 21,43 \\
\hline Median & 40 & 30 & 20 & 20 & 20 & 20 \\
\hline Standard deviation & 9,94 & 9,80 & 9,76 & 9,00 & 0,00 & 3,63 \\
\hline Minimum & 20 & 10 & 20 & 10 & 20 & 20 \\
\hline Maximum & 40 & 40 & 40 & 40 & 20 & 30 \\
\hline Size & 58 & 58 & 28 & 28 & 14 & 14 \\
\hline Inferior limit & 29,17 & 24,20 & 23,53 & 17,38 & - & 19,53 \\
\hline Superior limit & 34,28 & 29,25 & 30,76 & 24,05 & - & 23,33 \\
\hline $\mathrm{p}$-valor & \multicolumn{2}{|c|}{$0,007 *$} & \multicolumn{2}{|c|}{$0,013 *$} & \multicolumn{2}{|c|}{0,153} \\
\hline
\end{tabular}

TABLE 10. Comparison between the MRL for frequency modulated pure tone versus instrumental sounds filtered and normalized in amplitude and duration in normal hearing children at $4000 \mathrm{~Hz}$

\begin{tabular}{|c|c|c|c|c|c|c|}
\hline \multirow{2}{*}{$\begin{array}{l}4000 \mathrm{~Hz} \\
\text { Group I }\end{array}$} & \multicolumn{2}{|c|}{6 to $12 \mathrm{~m}$} & \multicolumn{2}{|c|}{13 to $24 \mathrm{~m}$} & \multicolumn{2}{|c|}{ over $24 \mathrm{~m}$} \\
\hline & PA & Sonar & PA & Sonar & PA & Sonar \\
\hline Average & 33,10 & 27,41 & 30,00 & 21,79 & 21,43 & 21,43 \\
\hline Median & 40 & 30 & 30 & 20 & 20 & 20 \\
\hline Standard deviation & 10,96 & 10,18 & 10,18 & 9,05 & 5,35 & 3,63 \\
\hline Minimum & 20 & 10 & 20 & 10 & 20 & 20 \\
\hline Maximum & 60 & 40 & 40 & 40 & 40 & 30 \\
\hline Size & 58 & 58 & 28 & 28 & 14 & 14 \\
\hline Inferior limit & 30,28 & 24,79 & 26,23 & 18,43 & 18,63 & 19,53 \\
\hline Superior limit & 35,92 & 30,03 & 33,77 & 25,14 & 24,23 & 23,33 \\
\hline p-value & \multicolumn{2}{|c|}{$0,005 *$} & \multicolumn{2}{|c|}{$0,002 *$} & \multicolumn{2}{|c|}{1,000} \\
\hline
\end{tabular}


TABLE 11. Comparison between the MRL for frequency modulated pure tone versus instrumental sounds filtered and normalized in amplitude and duration in children with bilateral sensorineural hearing loss at $1000 \mathrm{~Hz}$

\begin{tabular}{ccccccc}
\hline \multirow{2}{*}{$\begin{array}{c}c \\
\text { Group II }\end{array}$} & PA & Sonar & PA & Sonar & PA & Soner $25 \mathrm{~m}$ \\
\cline { 2 - 7 } & 80,00 & 79,00 & 80,00 & 76,25 & 78,33 & 77,08 \\
\hline Average & 80 & 80 & 80 & 80 & 80 & 80 \\
\hline Median & 0,00 & 3,16 & 0,00 & 7,19 & 5,65 & 9,99 \\
\hline Standard deviation & 80 & 70 & 80 & 60 & 60 & 40 \\
\hline Minimum & 80 & 80 & 80 & 80 & 80 & 80 \\
\hline Maximum & 10 & 10 & 16 & 16 & 24 & 24 \\
\hline Size & - & 77,04 & - & 72,73 & 76,07 & 73,09 \\
\hline Inferior limit & - & 80,96 & - & 79,77 & 80,59 & 81,08 \\
\hline Superior limit & & 0,330 & $\mathbf{0 , 0 4 6 *}$ & & 0,596 \\
\hline p-value & & &
\end{tabular}

\section{Discussion}

All children who took part in this study allowed the conclusion of the complete evaluation, the investigation of the MRL at four frequencies with two different stimuli, in only one session with an average time of 15 minutes. This result is similar to the one of Agostinho and Azevedo (2005) and a little longer than Schubert's study (2000), which was 11 minutes, however the author used only one type of acoustic stimulus, resulting in a quicker evaluation.

In Group I (children with normal hearing), the MRLs with the stimuli presented on the right were similar to the ones with the stimuli presented on the left, independently of the type of stimulus used. That is, the average MRL at the four frequencies did not differ between the sides of presentation, with either the frequency modulated pure tones or the instrumental sounds filtered and normalized in amplitude and duration.

This result was expected once children from this group presented normal hearing bilaterally, previously diagnosed in the Ambulatory of the Hearing Disorders Discipline, and thus responses with the same intensity levels were expected in both sides. This data agreed with the findings of Suzuki and Ogiba (1969), Lidén and Kankkunen (1969), Azevedo et al. (2001) and Agostinho and Azevedo (2005). Nevertheless, these studies used only the frequency modulated pure tone as a stimulus for the VRA.

Lidén and Kankkunen (1969) recommended the use of two lateral loudspeakers, because they believed that this way it would be possible to identify unilateral disorders through the differences between the thresholds obtained on the right and on the left, specially in high frequencies. According to the authors, in normal hearing people the same level of response would be expected bilaterally, which was observed in the present study.

In the specialized literature, no researches using the Sonar System in the VRA were found.

As well as in Group I, in Group II composed by children with bilateral sensorineural hearing loss it was observed that the differences between the average MRL found between the presentation sides (right and left) were not statistically significant, for either frequency modulated pure tones or the Sonar System stimuli. These data were also expected once children from this group present symmetrical bilateral hearing loss, without significant differences between the ears demonstrated in the ABR, in the TEOAE and DPOAE, and in the behavioral hearing assessment.

No studies were found in the researched bibliographic references about the MRL in children with hearing loss and, as mentioned before, there are no published studies using the Sonar System stimuli in the VRA that could be compared to the findings of the present study. 
Concerning the variable sex, in Group I the MRL for the frequency modulated pure tones did not differ significantly between the sexes, and the average MRL for the girls was $36,80 \mathrm{dBHL}(500 \mathrm{~Hz}) ; 31,20 \mathrm{dBHL}(1000 \mathrm{~Hz})$; $30,40 \mathrm{dBHL}(2000 \mathrm{~Hz})$ and $31,20 \mathrm{dBHL}(4000 \mathrm{~Hz})$ and the average for the boys was $36,00 \mathrm{dBHL}$ $(500 \mathrm{~Hz}) ; 28,40 \mathrm{dBHL}(1000 \mathrm{~Hz}) ; 27,20 \mathrm{dBHL}$ $(2000 \mathrm{~Hz})$ and $30,00 \mathrm{dBHL}(4000 \mathrm{~Hz})$.

These results do not agree with the ones from Azevedo et al. (2001) and Agostinho and Azevedo (2005), who found differences between the MRL of boys and girls. Both of them verified that girls presented better MRL, with a statistically significant difference. It is worth to stress that the study of Azevedo et al. (2001) was performed in the same conditions as the present study and in Agostinho and Azevedo (2005), the VRA was done with earphones.

Furthermore, in Group I it was observed a significant statistical difference between the sexes at $500 \mathrm{~Hz}$ and $2000 \mathrm{~Hz}$ : boys responded for weaker intensities with the Sonar System (table 2). These findings disagree with the results of Azevedo et al (2001) and Agostinho and Azevedo (2005) that, as mentioned before, used modulated pure tones as stimulus. In those studies, girls presented lower MRL than boys. The authors attribute this fact to the differences in the maturational processes between the sexes.

Soares et al. (1998) evaluated the MRL using white noise (wide band noise), a complex sound just like the ones from the Sonar System, and observed that male children present better responses than female children, agreeing with the present study. The average MRL for male children was 30dSPL and for female children, 35dBNPS (children from five to 11 months old) and 40dBNPS (children from 12 to 22 months old).

A possible hypothesis to justify this finding would be that complex sounds are more stimulant for male children. However, no researches on this hypothesis were found in the literature. There is only the Soares et al (1998) report, in which the average MRL with white noise was lower in male children.

In the group of children with bilateral sensorineural hearing loss (Group II) there was no difference in the MRL between the sexes for both types of stimuli. This could be justified by the similarity of the configuration and degree of children's hearing loss, either male or female.

Concerning the variable age, it was observed in group I that children from the first age group (six to 12 months) presented higher MRL for the frequency modulated pure tone than the other age groups (Table 3 and 4).

Comparing the MRL of children from the first age group with the ones from the second age group (12-24 months) there was a significant statistical difference at $500 \mathrm{~Hz}$ and $1000 \mathrm{~Hz}$. Additionally, comparing the MRL between the first age group and the third age group (>24 months), there was an evident statistical difference at all frequencies. Finally, when comparing the MRL between the second and the third age groups, it was observed a significant statistical difference only at $4000 \mathrm{~Hz}$ (Table 3 and 4 ).

Several studies also report a decrease of the MRL with the age increase, among them Suzuli and Ogiba (1961), Lidén and Kankkunen (1969), Northern and Downs (1991), Day et al. (2000), Azevedo et al. (2001), Sabo et al. (2003) and Agostinho and Azevedo (2005).

However, Sabo et al. (2003) distributed the sample in four age groups and found responses statistically superior in children from six to eight months than in children over nine months old. This difference was seen at the four evaluated frequencies with frequency modulated pure tone.

In the present study, the significant statistical difference at all tested frequencies occurred when comparing children from 6 to 12 months to the ones over 24 months.

Comparing the average MRL of the present study to the ones obtained in other studies, it was observed similar levels to the ones obtained by Suzuki and Ogiba (1961), Lidén and Kankkunen (1969) and Versolatto (2005), in children below 12 months. All mentioned studies, except Versolatto (2005), used the same evaluation methodology: sound proof room, two amplifiers and frequency modulated pure tone.

Versolatto (2005), despite using only one amplifier and performing the evaluation in a sound proof room, but not a cabin, observed MRL from 27,7 to $36,2 \mathrm{dBHL}$, similar to the ones obtained in this study.

Nevertheless, when investigating the MRL in 70 children below one year of age, Sabo et al. (2003) obtained MRL lower than the ones 
obtained in this study with children of the same age. This difference could be attributed to the type of acoustic cabin used and/or the type of visual stimulus presented. In Sabo et al. (2003) the visual stimulus presented was an animated toy and in the present study it was three red lights when using the pediatric audiometer, and a lighted not moving clown when using the Sonar System. Schmida et al. (2003) and Jayarajan et al. (2005) affirm that the use of animated toys or images is more stimulant for the pediatric population.

It was observed in the present research a MRL lower than the ones presented by Northern and Downs (1991) and Azevedo et al (2001) in the age group below 12 months. A possible explanation for this difference would be that in this study the hearing evaluations were performed in sound proof cabins and in Northern and Downs (1991) and Azevedo et al (2001) the evaluations were performed in sound proof rooms and not cabins.

Analyzing the MRL of children over 12 months, the MRL averages of the present study are similar to the ones found by Suzuki and Ogiba (1961) and Northern and Downs (1991). Such findings disagree with the ones obtained by Sabo et al. (2003), who registered lower MRL probably due to the type of visual reinforcement used in the VRA and/or sound proof cabin used.

Agostinho and Azevedo (2005), evaluated children aging between 12 and 16 months using earphones and obtained lower MRL than the present study, specially when analyzing the female sample. It's worth to stress that the authors present the MRL according to the sex, because they found significant statistical difference between the sexes. These differences were expected once the VRA with earphones predispose better responses.

Still regarding group I, when analyzing the MRL for the instrumental sounds from the Sonar System, it was observed that children from the first age group (6-12 months), presented higher MRL than the other age groups (Table 5 and 6 ).

Comparing the MRL of the first age group with the second age group (12-24 months), there was a significant statistical difference at $1000 \mathrm{~Hz}, 2000 \mathrm{~Hz}$ and $4000 \mathrm{~Hz}$, besides a tendency for a difference at $500 \mathrm{~Hz}$. Additionally, when comparing the MRL of the first age group with the third age group (>24 months), it was evidenced a significant statistical difference only at $500 \mathrm{~Hz}$. Finally, comparing the MRL between the second and the third age groups, there was no significant statistical difference at any tested frequency (Table 5 and 6).

As there are no studies in the literature on VRA using the Sonar System, it may be hypothesized that as well as the frequency modulated pure tones the responses tend to decrease with the age increase, justified by the child maturation and development.

In Group II, composed by children with bilateral sensorineural hearing loss, there was no significant statistical difference between the MRL of the age groups, at any frequency with both types of stimuli.

This finding is probably because the majority of children presented severe to profound hearing loss. Thus, all of them presented very similar MRL, independently of the age group.

Regarding the type of stimulus, as there was a significant statistical difference between the MRL averages according to the age groups, the MRL was compared by stimulus and age group.

In group I it was observed that the MRL for the instrumental sounds of the Sonar System are statistically lower than the MRL for frequency modulated pure tones in the younger age groups (6 to 12 months and 13 to 24 months), at all tested frequencies (Table 7, 8, 9 e 10).

This is probably related to the type of visual reinforcement used. In the VRA with frequency modulated pure tones, the visual reinforcement used was three red lights (red dots that blink) of the pediatric audiometer. In the VRA with instrumental tones of the Sonar System, a lighted clown was used as visual reinforcement. The lighted clown is a more attractive visual reinforcement than the three red lights, once the clown is a known character by most of the children. This could have influenced the MRL obtained with the Sonar System stimulus.

Furthermore, the presentation of the sound stimuli of the Sonar System was decreasing from 10 to $10 \mathrm{~dB}$ and the modulated tones, from 20 to $20 \mathrm{~dB}$ due to limitations of the PA2, which could also be considered a factor that interfered in the MRL favoring the Sonar System. 
Another possible reason for these findings is the fact that the Sonar System stimuli preserve the complex sounds characteristics, maintaining even the percussion rhythm of the musical instruments, although the signals are filtered and present effective energy only at specific frequency bands (Lima et al., 2001). Furthermore, stimuli with such characteristics are more meaningful and more stimulating for small children (Poblano et al., 2000 and Chirelli et al., 2002).

Jerger et al. (1974) add that complex sounds, such as for example the white noise present $\mathrm{N}$ frequencies that would provoke a central sensation of "intensity summation", giving the hearing people an impression of a sound with a stronger intensity than the real one. This could be an argument to justify the lower MRL obtained with the Sonar System stimuli, which are similar to complex sounds, when compared to the modulated pure tones.

The same would not happen with children with hearing loss, since the greater the degree of the loss the lesser the number of audible frequencies and the lesser the central summation. The result would be a reduction in the use of the intensity offered by the complex sound, and thus there would not be differences between the response levels for different types of stimuli, which was evidenced in the actual study. In group II, the average MRL is numerically inferior with the Sonar System instrumental sounds at $500 \mathrm{~Hz}$,
$1000 \mathrm{~Hz}$ and $2000 \mathrm{~Hz}$ in the three age groups. However, this difference was statistically significant only at $1000 \mathrm{~Hz}$ in the second age group (children from 13 to 24 months).

\section{Conclusion}

In the end of this study it was possible to establish the following conclusions:

. the MRL did not vary according to the presentation side for either normal hearing children or the ones with hearing loss.;

. there was a significant statistical difference only at $500 \mathrm{~Hz}$ and $2000 \mathrm{~Hz}$ regarding the sex, with instrumental stimulus of the Sonar System in the group of normal hearing children: male children presented lower MRL than female children;

. there was a significant statistical difference between the MRL regarding the variable age for the group of normal hearing children, independently of the type of sound stimulus used; the same did not happen with children with hearing loss;

. there was a significant statistical difference between the MRL regarding the variable type of stimulus: children with normal hearing aging less than 24 months presented lower minimum response levels with the Sonar System stimulus. This difference didn't occur in children with hearing loss.

\section{References}

AGOSTINHO, C. V.; AZEVEDO, M. F. Audiometria com reforço visual com fones em crianças de 5 a 16 meses de idade. R. Fono Atual, São Paulo, v. 32, n. 8, p. 25-32, 2005.

AITA, A. D. C.; MESQUiTA, C. D. S.; NUNES, B. G.; PINTO, L. C. V.; FERREIRA, M. A. Triagem auditiva de 0 a 2 anos: uma proposta para as unidades básicas de saúde. Fonoaudiol. Brasil, Brasilía, v. 2, n. 2, p. 55-68, dez. 2002.

AZEVEDO, M. F.; VIEIRA, R. M.; VILANOVA, L. C. P. Desenvolvimento auditivo de crianças normais e de alto risco. São Paulo: Plexus, 2001.
CHIRELli, A. M.; SOARES, E.; ARAÚJO, F. C. R. S Análise espectral psicoacústica de instrumentos não calibrados: uma contribuição para a avaliação comportamental infantil. In: PANHOCA, I. Tempo de fonoaudiologia. Taubaté: Cabral, 2002. cap. 13.

DAY, J.; BAMFORD, J.; PARRY, G.; SHEPHERD, M.; QUIGLEY, A. Evidence on the efficacy of insert earphone and sound field VRA with young infants. Br. J. Audio., v. 34 , n. 6, p. 229-334, dec. 2000. 
DELAROCHE, M.; THIEBAUT, R.; DAUMAN, R. Behavioral audiometry: protocols for measuring hearing thresholds in babies aged 4-18 months. Inter. J. Pediatr. Otorhinolaryngol., v. 68, n. 10, p. 1233-1243, oct. 2004.

JACOBSON, J.; JACOBSON, C. Evaluation of hearing loss in infants and young children. Pediatr. Annals., v. 33, n. 12, p. 811-821, dec. 2004.

JAYARAJAN, V.; NANDI, R.; CALDICOTT, B. An innovation in insert visual reinforcement audiometry in children. J. Laryn Otol., v. 199, n. 2, p. 132-133, feb. 2005.

JERGER, J.; BURNEY, P.; MAULDIN, L.; CRUMP, B. Predicting hearing loss from the acoustic reflex. J. Speech Hear. Disord., v. 39, n. 1, p. 11-22, feb. 1974.

LICHTIG, I.; MONTEIRO, S. R. G.; COUTO, M. I. V.; HARO, F. M. B.; CAMPOS, M. S. C.; VAZ, F. A. C.; OKAY, Y. Avaliação do comportamento auditivo e neuropsicomotor em lactentes de baixo peso ao nascimento. R. Med. Br., v. 47, n. 1, p. 52-58, jan.-mar. 2001.

LÍDEN, G.; KANKKUNNEN, A. Visual reinforcement audiometry. Acta. Otolaryngol., v. 67, n. 2, p. 281-292, jun. 1969

LIMA, M. C. M. P.; ARAÚJO, A. M. L.; ARAÚJO, F. C. R. S. Sistema Sonar: sons normalizados para a avaliação audiológica. Carapicuíba (SP): Pró-Fono, 2001.

NORTHERN, J. N.; DOWNS, M. P. Behavioral hearing testing of children. In:___ Hearing in children. Baltimore: Williams \& Wilkins, 1991. cap. 4.

ODA, A. K.; BERNARDI, A. P. A.; AZEVEDO, M. F. Comparação dos limiares auditivos tonais determinados por tom puro e por tom modulado. $R$. Cefac., v. 5, n. 2, p. 149-156, abr.-jun. 2003.

OLIVEIRA, T. M. T.; COSER, P. L.; MACHADO, M. S.; COSTAMILAN, C. M.; DANIEL, R. C. Identificação e intervenção precoce na deficiência auditiva infantil. Pediatr. Atual, v. 15, n. 3, p. 41-46, 2002.

POBLANO, A.; CHAYO, I.; IBARRA, J.; RUEDA, E. Electrophysiological and behavioral methods in early detection of hearing impairment. Arch. Med. Res., v. 31, n. 1, p. 75-80, jan.-fev. 2000.
SABO, D. L.; PARADISE, J. L.; KURS-LASKY, M.; SMITH, C. G. Hearing levels in infants and young children in relation to testing technique, age group, and the presence or absence of middle-ear effusion. Ear Hear., v. 24, n. 1, p. 38-47, apr. 2003.

SCHIMIDA, M. J.; PETERSON, H. J.; THARPE, A. M. Visual reinforcement audiometry using digital video disc and convencional reinforcers. Am. J. Audiol., v. 12, n. 1, p. 35-40, jun. 2003.

SCHUBERT, S. H. Avaliação audiológica em crianças de 6 a 24 meses de idade utilizando a audiometria de reforço visual informatizado. 2000. Dissertação (Mestrado) Pontifícia Universidade Católica, São Paulo.

SININGER, Y. S. Audiologic assessment in infants. Audiol., v. 11 , n. 5, p. 378-382, oct. 2003.

SIRIMANNA, K. S. Management of the hearing impaired infant. Semin. Neonatol., v. 6, n. 6, p. 511-519, dec. 2001.

SOARES, E.; RIBEIRO, R.; AZEVEDO, M. F. Estudo dos níveis mínimos de resposta para estímulo verbal, ruído branco e tom puro em crianças de 5 meses a 22 meses de idade. Pró-Fono R. Atual. Cient., Carapicuíba (SP), v. 10 n. 1, p. 30-33, jan.-abr. 1998.

SUZUKI, T.; OGIBA, Y. Conditioned orientation reflex audiometry. Arch. Otolaryngol., v. 74, p. 192-198, 1961.

VERSOLOLATTO, M. C. M. Relações entre desenvolvimento sensório motor, características individuais e desempenho na audiometria de reforço visual em crianças de cinco a nove meses de idade. 2005. Dissertação (Mestrado) - Pontifícia Universidade Católica, São Paulo.

WIDEN, J. E.; FOLSOM, R. C.; CONE-WESSON, B.; et al. Identification of neonatal hearing impairment: hearing status at 8 to 12 months corrected age using a visual reinforcement audiometry protocol. Ear Hear., v. 21, n. 5, p. 471-487, oct. 2000

WIDEN, J. E.; O'GRADY, G. M. Using visual reinforcement audiometry in the assessment of hearing in infants. Hear. J., v. 55, n. 1, p. 28-36, jun. 2002. 
Pró-Fono Revista de Atualização Científica, v. 19, n. 2, abr.-jun. 2007 